\title{
Waste to Sustainable Biohydrogen Production Via Photo-Fermentation and Biophotolysis - A Systematic Review
}

\author{
George Melitos(D, Xenofon Voulkopoulos, and Anastasia Zabaniotou ${ }^{*}$ (D \\ Chemical engineering Department, Aristotle University of Thessaloniki, Greece
}

Received: 25 July 2021 / Received in final form: 15 October 2021 / Accepted: 15 October 2021

\begin{abstract}
Considering the environmental challenges humanity faces in the 21st century, it is obvious that there is an enormous need for change of the global energy map. Under these circumstances, new energy sources and intermediates must be considered as options to limit the greenhouse gases emissions and mitigate climate crisis. Biohydrogen production is one of the most appealing options, due to hydrogen's multiple applications and zero emissions as a fuel, to empower a future hydrogen circular economy. In this review article we focus on two methods that are not widely used at industrial scale but have many future possibilities and growth margins: (a) photo-fermentation and (b) bio photolysis. Both methods are light dependent and need photobioreactors to function and produce significant amounts of biohydrogen. Based on an extensive literature search and systemic analysis of the findings, presentation of the different reactants, operating conditions and biohydrogen productions, key factors and effecting parameters were discussed. Temperature, pH, light intensity and photobioreactor operation and design are some of the most significant factors that define the biohydrogen production rates and yields. Innovative solutions and approaches are presented including biotechnological and genetic engineering modifications to microorganisms, as well as combinations of some hybrid biohydrogen producing methods, especially dark and photo fermentation. For implementing a biohydrogen circular-economy, different wastes were explored as potential feedstocks, and overcoming of major bottlenecks that biophotolysis and photo-fermentation face in the transition to a sustainable biohydrogen economy, were discussed.
\end{abstract}

\section{Introduction}

The demand for clean energy sources in the new world has opened the way for research and development (R\&D) of hydrogen production. Hydrogen will contribute about $80 \%$ of total energy demands until 2025. Hydrogen's emerging potential technology is significant, due to its application as fuel, electricity generation and valuable chemicals production [1]

Hydrogen is a chemical element with many applications and uses, and it can be characterized as the chemical of the future. It can be used for energy production, especially for heat and electricity, as well as to produce many useful products for the chemical industry like ammonia and methanol. It can be used as a fuel in internal combustion engines (ICE) or in fuel cells (FCs). Hydrogen as a fuel is capable of powering cars, trains, bushes and even airplanes or ships. This use of hydrogen is very important because its combustion has negative emissions. The only by-product is water. Comparing to all other fossil fuels

\footnotetext{
* e-mail: azampani@auth.gr
}

and biofuels, hydrogen is one of the few that does not include carbon, resulting in lower and sometimes zero greenhouse gases [2]. Moreover, hydrogen as a fuel is more efficient compared to conventional fuels. Furthermore, biohydrogen production methods offer the advantage of biodiversity and are more environmentally efficient, comparing to conventional hydrogen producing methods like electrolysis, gasification, or steam reforming.

Because of its abundance on the universe, hydrogen also appears in big quantities on earth. However, hydrogen does not appear in its molecular form but in many chemical compounds such as water or organic material. The need of separating hydrogen from its compounds and use it on its own, has led to the development of numerous methods for hydrogen production. Some of them are already used in large scale, while others are still on an early stage of development and need further research to become sustainable.

The most common chemical processes to produce hydrogen are electrolysis, steam methane reforming and gasification [3]. Another path is the biological path. When hydrogen is produced via a biological process it is called bio-hydrogen. A schematic illustration of most hydrogen production methods is shown in Figure 1. 


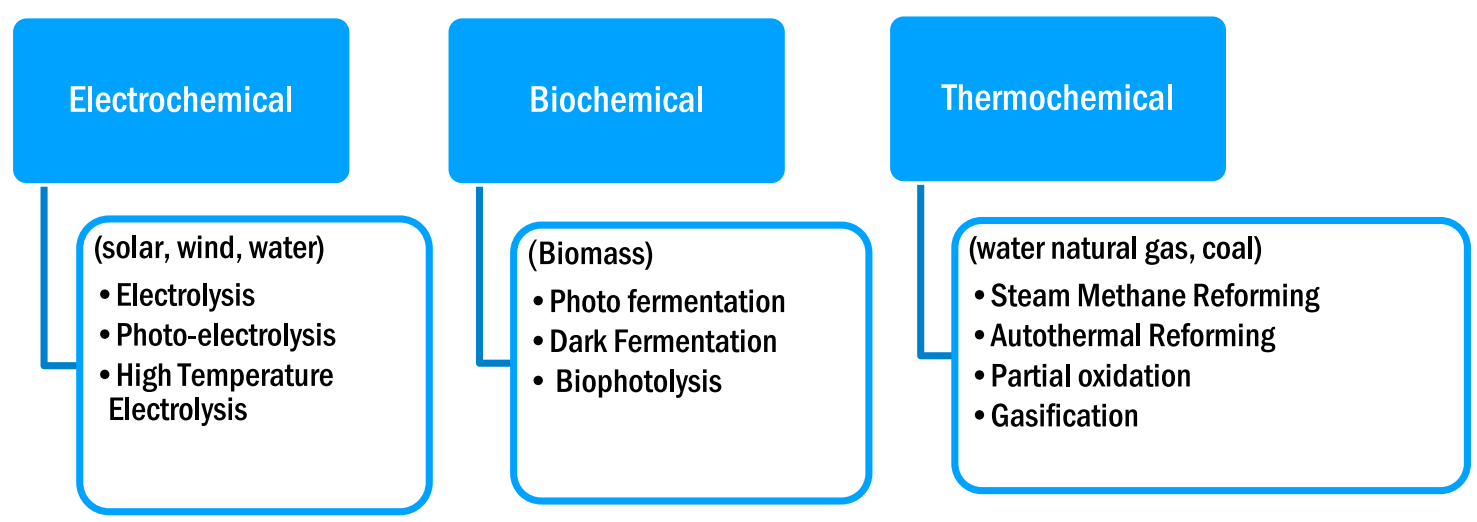

Fig. 1. Pathways of hydrogen production.

However, the production of hydrogen at commercially viable prices has been very difficult to achieve. Many hydrogen applications neglected to account versatile the market prices and highly limited availability of the hydrogen. Internal combustion engines using hydrogen (or adding it as a "sweetener"), and many other potential applications are economically limited by the input price for bulk hydrogen production, storage, transport, and safe handling. Furthermore, large hydrogen usage has some additional drawbacks and bottlenecks. Hydrogen storage is a very complex subject and even though there are some technologies available, the problem of hydrogen storage is yet to be solved. Moreover, there are some safety issues that the hydrogen industry must overcome. Hydrogen leaks are extremely dangerous because it does not have any smell or color so it cannot be identified [4].

Nearly all industrial hydrogen nowadays is produced from methane derived primarily from natural gas, although oil and coal are also used (fossil sources). However, to meet the growing world demand for hydrogen, and for natural gas to be an important driver of hydrogen production, the natural gas prices must remain low. The two most common processes of industrial hydrogen production, electrolysis and steam reforming of methane/natural gas (with approximately $5 \%$ and $95 \%$ of current production, respectively), are expensive for the amount of hydrogen produced and often require initial capital expenditures exceeding several million dollars. In addition, transport and storage costs are high, requiring large, heavy tanks designated for hazardous materials transport. Steam reforming, which allows for very high production rates, can only be applied at massive, highly complex industrialscale chemical plants that require direct sources of methane/natural gas and operate at very high temperature and pressure [4].

Despite all the global R\&D efforts, more than $95 \%$ of hydrogen is produced using fossil fuels, therefore the produced hydrogen is not a "clean and green" fuel while electrolysis that is the major hydrogen production process is exceedingly inefficient, expensive, and energy-intensive while methods involving renewable energy sources are still far from being economic or commercially cost-competitive [4]. Solar hydrogen production is the subject of intensive research efforts nowadays, that are mainly devoted to the development of materials and processes for solar hydrogen production by light-driven dissociation of water into oxygen and hydrogen, associated with the intermittent nature of sunlight, by decoupling energy generation and consumption [5].

In this article, the processes for biohydrogen production that are selected to be reviewed are: (a) photo-fermentation and (b) bio photolysis. These two innovative methods were exclusively selected for the following reasons:

- They are not widely used at industrial scale.

- They provide many prospects and growth margins.

- Both methods are light dependent.

- Both methods need photobioreactors to function.

- Both methods produce significant amounts of biohydrogen.

Furthermore, towards a circular bioeconomy (CBE), various wastes were investigated as feedstocks for biohydrogen production from renewable sources.

Towards the transition to a sustainable biohydrogen economy, overcoming the major bottlenecks that biophotolysis and photo-fermentation face, were also discussed.

\section{Methodology}

In this paper, an extended literature review was performed, mainly based on internationally published articles. The purpose was to collect data about the processes and sustainability of photo-fermentation and biophotolysis as biohydrogen production methods. It must be mentioned that the selection of all the articles was made with a critical point of view.

The bibliographic databases used for collecting articles were Science Direct (2009-2020) and Scopus (2009-2020). The search for articles regarding this study's topic resulted to an excessive number of results. Many adjustments on specific criteria implemented to make the number of the articles manageable.

The first searched topics were: "Biohydrogen production AND photo-fermentation", "Biohydrogen production AND biophotolysis" and "Biohydrogen production AND photofermentation and biophotolysis". According to Table 1, a significant number of papers about both methods was found, but photo-fermentation seemed to attract more scientific interest than biophotolysis. The total amount of papers searched regarding photo-fermentation amounted 743 , while the papers regarding biophotolysis reached 489 . The results for every search topic are presented in Table 2 and in Figure 2. 
Table 1. Review of the bibliographic results.

\begin{tabular}{llll}
\hline Keywords/Topic & Science Direct & Scopus & Published papers (2009-2020) \\
\hline $\begin{array}{l}\text { 1. Biohydrogen Production } \\
\text { AND Photofermentation }\end{array}$ & 541 & 202 & 743 \\
$\begin{array}{l}\text { 2. Biohydrogen Production } \\
\text { AND Biophotolysis }\end{array}$ & 428 & 61 & 489 \\
$\begin{array}{l}\text { 3. Biohydrogen Production } \\
\text { AND Photofermentation }\end{array}$ & 223 & 31 & 254 \\
AND Biophotolysis & & & \\
\hline
\end{tabular}

Table 2. Biohydrogen production via photo-fermentation' bibliographic results.

\begin{tabular}{llll}
\hline Years & Science Direct & Scopus & Published papers \\
\hline 2009 & 17 & 4 & 21 \\
2010 & 24 & 18 & 42 \\
2011 & 45 & 18 & 63 \\
2012 & 41 & 22 & 63 \\
2013 & 45 & 16 & 61 \\
2014 & 29 & 11 & 40 \\
2015 & 37 & 20 & 57 \\
2016 & 44 & 16 & 60 \\
2017 & 39 & 18 & 57 \\
2018 & 54 & 15 & 69 \\
2019 & 80 & 17 & 97 \\
2020 & 86 & 27 & 113 \\
Total number & 541 & 202 & 743 \\
\hline
\end{tabular}

A year-by-year analysis was made to explore the increase or decrease in the scientific interest for each year since 2009. Moreover, it was able to find the breakthrough years in which photo-fermentation and biophotolysis methods had important amounts of research outcomes. The year-by-year results for every search topic are presented at Tables $2-4$ and a schematic illustration combining the results from all three Tables is presented at Figure 3.

The main outcome from Tables $2-4$ and Figure 3 is that there is a growing scientific interest for photo-fermentation and biophotolysis. In all three research topics, it can be easily observed that the year 2020 (year of the study) is the year with the most papers published.

The search continued by adding the keyword "Sustainable" (on the research topic biohydrogen production AND photo-fermentation and biophotolysis). This search resulted in 235 publications. After a first screening, 169 publications selected including review articles. In the next screening, specific scientific subject areas which are associated with this paper's subject have given importance, which are the following:

- Energy.

- Chemistry.

- Chemical Engineering.

- Engineering.

- Environmental Sciences.
- Biochemistry, Genetics and Molecular Biology.

- Immunology and Microbiology.

- Agricultural and Biological Sciences.

After this second screening, the papers reduced to 136 . Finally, a last detailed screening took place in which the 136 papers processed one by one to determine if they are useful for this study or not. Many papers were not relative to this study, so from 136 papers only 36 considered useful for this study. The detailed screening steps are described in Table 5 .

\section{Processes fundamentals}

\subsection{Photo-fermentation}

It is an innovative route for biohydrogen production where a carbon source is being converted to biohydrogen by using photosynthetic bacteria. A key addition to the whole process is the light energy, natural or artificial. The photosynthetic bacteria mainly used are called purple nonsulfur bacteria (PNS bacteria). Rare, green bacteria and purple bacteria are used too. The light energy is used to oxidize the carbon source and produce electrons. PNS bacteria (and the other bacteria that can be used) synthesize nitrogenase or hydrogenase enzymes. Especially nitrogenase is the main enzyme responsible for hydrogen formation. The method takes place under anaerobic 


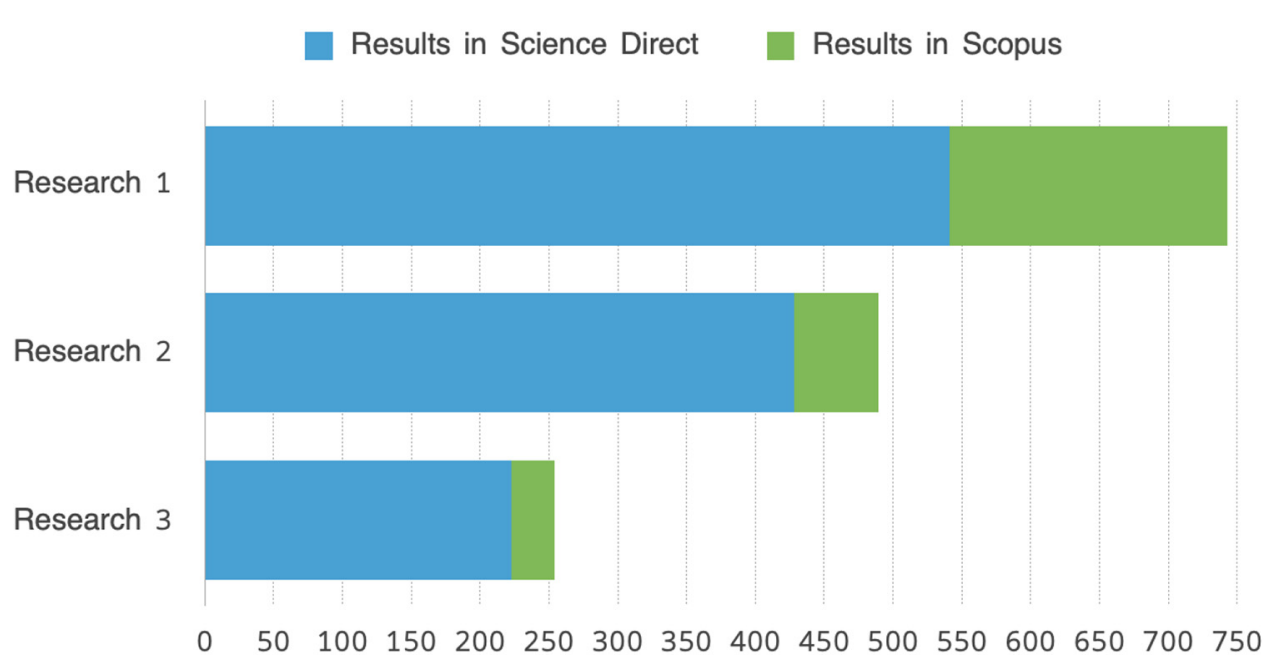

Fig. 2. Paper's contribution in each research topic.

Table 3. Biohydrogen production via biophotolysis' bibliographic results.

\begin{tabular}{llll}
\hline Years & Science Direct & Scopus & Published papers \\
\hline 2009 & 14 & 2 & 16 \\
2010 & 18 & 2 & 20 \\
2011 & 42 & 6 & 48 \\
2012 & 29 & 4 & 33 \\
2013 & 32 & 8 & 40 \\
2014 & 23 & 4 & 27 \\
2015 & 30 & 5 & 35 \\
2016 & 38 & 5 & 43 \\
2017 & 33 & 10 & 43 \\
2018 & 41 & 5 & 46 \\
2019 & 57 & 4 & 61 \\
2020 & 71 & 6 & 77 \\
Total Number & 428 & 61 & 489 \\
\hline
\end{tabular}

Table 4. Sustainable Biohydrogen production via photo-fermentation and biophotolysis' literature search results.

\begin{tabular}{llll}
\hline Years & Science Direct & Scopus & Published papers \\
\hline 2009 & 3 & 1 & 4 \\
2010 & 4 & 2 & 6 \\
2011 & 20 & 4 & 24 \\
2012 & 13 & 4 & 17 \\
2013 & 23 & 6 & 29 \\
2014 & 12 & 1 & 13 \\
2015 & 15 & 3 & 18 \\
2016 & 22 & 2 & 24 \\
2017 & 14 & 2 & 16 \\
2018 & 22 & 2 & 24 \\
2019 & 37 & 2 & 39 \\
2020 & 38 & 2 & 40 \\
Total Number & 223 & 31 & 254 \\
\hline
\end{tabular}


Photo-fermentation and Biophotolysis Photo-fermentation

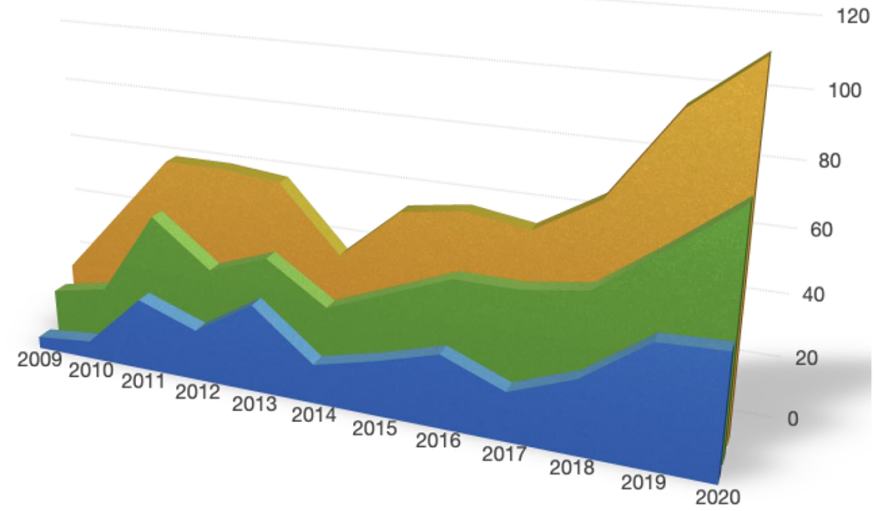

Fig. 3. 3D presentation of the year-by-year analysis of literature search results.

conditions. Nitrogenase under anaerobic conditions use electrons and ATP (Adenosine triphosphate) and produce hydrogen and ADP (Adenosine diphosphate), as it described by the equation (1) [6].

$$
2 \mathrm{H}^{+} 2 \mathrm{e}^{-}+4 \mathrm{ATP} \rightarrow H_{2}+4 \mathrm{ADP}+\mathrm{Pi}
$$

The conditions ( $\mathrm{pH}$, temperature, and light intensity) depend mainly on the specific bacteria used and the carbon source that is converted. The most effective $\mathrm{pH}$ and temperature conditions are $6.8-7.5$ and $30-35{ }^{\circ} \mathrm{C}$, while the optimal light intensity range from 6 to 6000 lux [6].

Via photo fermentation, apart from molecular hydrogen, small amounts of $\mathrm{CO}_{2}$ are produced. An example of a photo fermentative reaction using acetate as organic source and PNS (purple non-sulfur) bacteria is shown in equation (2) [7].

$$
\begin{aligned}
2 \mathrm{CH}_{3} \mathrm{COOH}+2 \mathrm{H}_{2} \mathrm{O} & \rightarrow 4 \mathrm{H}_{2}+2 \mathrm{CO}_{2}, \Delta \mathrm{G}_{0} \\
& =+104 \mathrm{~kJ}
\end{aligned}
$$

In most studies, photo fermentation takes place in a batch photo bioreactor, in a cylindrical bioreactor or in a continuous stirred tank bioreactor (CSTBR). Studies have proven that the hydrogen production rate is significantly lower than the theoretical production rate based on the equations which is the main drawback of photo fermentation. To enhance the hydrogen productivity and method's sustainability many key factors have been optimized. The results are very promising, although many barriers still prevent from industrial application [7].

\subsection{Biophotolysis}

The second method is biophotolysis that uses microorganisms (for example cyanobacteria or microalgae) to produce biohydrogen from water. An important factor is the sunlight, which is essential for the system to produce biohydrogen. Water is not the only reactant that can be used in these processes. Glucose as well as other organic matter can be used in biophotolytic processes. This method of hydrogen production has been applied in different ways through the years, most at laboratory scale. Biophotolytic processes can be categorized into two main categories: direct biophotolysis and indirect biophotolysis. The general chemical reaction that describes these 2 processes is given by the reaction (3) [8].

$$
2 \mathrm{H}_{2} \mathrm{O}+\text { light energy } \rightarrow 2 \mathrm{H}_{2}+\mathrm{O}_{2}
$$

In the process of direct biophotolysis, the photosystem absorbs the light energy and transport electrons to ferredoxin. This phenomenon results to the reduction of water [7]. The reduced ferredoxin can transport electrons to hydrogenase (biohydrogen producing enzyme). After that, hydrogenase catalyzes the conversion of a proton to biohydrogen, according to the reaction (4), [9].

$$
2 \mathrm{H}^{-}+2 \mathrm{FD}^{-} \rightarrow \mathrm{H}_{2}+2 \mathrm{FD}
$$

According to the general equation (3) of biophotolysis, oxygen is getting produced as well. This amount of oxygen inhibits the activity of hydrogenase enzyme and is a major problem in direct biophotolytic systems.

Indirect biophotolysis is a process that takes place in two stages. In the first step the photosynthetic system produces a big amount of biomass to increase the amount of carbohydrate. In the second step the biomass rich carbohydrate is being utilized as carbon source. This carbon source plays a similar role to water in direct biophotolysis. This second stage has some similarities with anaerobic fermentations processes. The advantage of indirect biophotolysis comparing to the direct one, is that the stage of oxygen generation is separated from the stage of hydrogen evolution, so oxygen is not inhibiting the $\mathrm{H}_{2}$ evolution $[7,9]$.

\section{Processes parameters}

\subsection{Substrates}

There are plenty of substrates used in photo biological processes, leading to different hydrogen production yields. Pure organic chemical substances (acetate, butyrate, malate etc.) have been used widely in research, to determine which of them is the most efficient for biohydrogen production [10].

However, the most sustainable and feasible way of producing biohydrogen in large scale is by using different types of wastes. Different types of wastes have been studied, for example food wastes (wheat straw, rice straw etc.), wastewaters (tofu, diary, brewery etc.). Each of these wastes contain different carbon source, which directly affects the production [11].

Another important factor that can improve or decrease the process efficiency is the color of the waste that is being used. Some wastewaters have dark color which inhibits the light absorption, so they need a pretreatment or dilution method of the waste [12]. Another reason for pretreatment may be the toxic nature of the substrate or its opaqueness [13]. 
Table 5. Consecutive screening regarding the 'sustainable biohydrogen production' bibliographic search.

\begin{tabular}{lll}
\hline Screening Stage & Screening Methodology & Published papers \\
\hline 1 & Publication years 2009-2020 & 234 \\
2 & Review and Research Articles & 168 \\
3 & Articles in a specific subject area & 135 \\
4 & Articles relative with our study & 36 \\
\hline
\end{tabular}

Table 6. Optimal pH values for specific species of algae and bacteria.

\begin{tabular}{lll}
\hline Bacteria/Algae & pH values & References \\
\hline Rhodopseudomonas palustris & $6.7-7.2$ & {$[1]$} \\
Clostridium Species & $5-6$ & {$[16]$} \\
Rhodobacter sphaeroides & $6.8-7.2$ & {$[11]$} \\
Rhodobacter Capsulatus & 7 & $[1]]$ \\
Chlamydomonas reinhardtii & 7 & {$[17]$} \\
Chlamydomonas MGA 161 & 8 & {$[17]$} \\
Cyanobacterium Synechocystis and Cyanobacterium Gleocapsa & $6.8-8.3$ & {$[14]$} \\
Oleaginous Microalgae & 6.8 & {$[18]$} \\
\hline
\end{tabular}

Pretreatment of the carbon source is one of the most important steps in a biohydrogen production process, because with pretreatment methods components that may inhibit the process efficiency can be degraded. The pretreatment can be achieved by plenty of methods following a chemical, physical, physicochemical, or biological path [1].

\subsection{Photobioreactor's type}

There is a respectable amount of photobioreactors that has been used in photo fermentation and biophotolysis processes. The two main categories of photobioreactors are the open system bioreactors and closed system bioreactors [9].

\subsubsection{Open air bioreactor systems}

The open-air bioreactor system usually looks like a shallow pond in which the cultivation conditions are ambient, and they usually operate in a continuous mode. The main advantages of an open air photobioreactor systems are their low energy demands and their low cost [14]. Although in these systems the maintenance of the optimum conditions becomes difficult so in some cases closed system photobioreactors are favorable [9].

\subsubsection{Closed system bioreactors}

In this category, there is a big number of different reactors, (tubular, flat, column, V-shaped panel and stirred tank photobioreactors) $[9,14]$. They can operate both is batch, semi continuous or continuous mode, although their operation mode affects the hydrogen production rate.

\section{$4.3 \mathrm{pH}$}

$\mathrm{pH}$ is a very important efficiency factor for the photo biological processes. Each process with different substrates and microbial organisms has its optimum $\mathrm{pH}$ conditions, as $\mathrm{pH}$ regulates various metabolic pathways [9]. Generally, acidophilic conditions enhance biohydrogen production in biophotolytic and photo-fermentative processes [10].

The control of the $\mathrm{pH}$ in such processes is a challenge because some organic acids (for example volatile fatty acids) appear in the system as by-products. This acidogenesis leads to the decrease of $\mathrm{pH}$ in the reactor during time and the system loses its buffering capacity. The maintenance of $\mathrm{pH}$ in an optimal range is crucial for the maintenance of hydrogen production [15]. This optimal $\mathrm{pH}$ range for each process especially will be discussed in the next chapter, although it's worth mentioning that both in photo-fermentation (with PNS bacteria) and biophotolysis (with microalgae and cyanobacteria) this range varies between 5 and $8[10,14,15]$. Table 6 includes the optimal $\mathrm{pH}$ for specific bacteria and algae.

\subsection{Temperature}

Temperature is one of the physicochemical key factors of a photo biological system. Keeping temperature at some optimal values enhances the system's efficiency. The temperature in such systems mediates the enzymatic reactions, so it controls the metabolism of the enzymes [14].

Temperature can lead to higher biohydrogen production by altering the metabolic pathways [19]. Every enzyme has its own optimal temperature range at which high activity is observed [14]. It is important to mention that anaerobic processes are strongly temperature-dependent, and there is a scientific disagreement about the optimal 
Table 7. Most efficient performing temperatures using microorganisms.

\begin{tabular}{lll}
\hline Bacteria/Algae & Temperature $\left({ }^{\circ} \mathrm{C}\right)$ & References \\
\hline MIcroalgae & $20-30$ & {$[20]$} \\
Cyanobacteria & $25-55$ & {$[17,21]$} \\
PNS bacteria & $25-35$ & {$[22]$} \\
\hline
\end{tabular}

temperature conditions in photo-fermentative and biophotolytic processes [14]. However there has been a determination in the optimal temperature values for specific experiments using microalgae, cyanobacteria an PNS bacteria. In biophotolytic processes, ambient temperatures are favorable, (in a range of $20-35^{\circ} \mathrm{C}$ ), although in some cyanobacteria strains even thermophilic temperatures $\left(55^{\circ} \mathrm{C}\right)$ are suitable.

Table 7 presents the most efficient temperature ranges that have been observed in experiments using microorganisms.

It can be observed that bioprocesses for hydrogen production can take place in ambient temperatures in contrast with the conventional processes for producing hydrogen (gasification, steam methane reforming) which take place in very high temperature levels.

\subsection{Light intensity}

Light is an integral part both in photo-fermentation and biophotolysis because it supplies the biohydrogen producing systems with the required energy which is stored on the form of ATP molecules generated by photosynthesis [11].

The light source can be the sun or artificial. In photofermentation the intensity and the wavelength of the light source directly affects the bacterial system. As the light intensity increases it enhances the hydrogen production until the light saturation point. The light saturation point is not standard, and it depends on the microorganisms used in the system. For a standard culture of PNS bacteria the optimal light intensity range lies between 4000 and 5000 lux. After the value of 5000 lux (saturation point) the hydrogen production decreases $[22,23]$. However, this saturation point can change if the culture conditions change in the system. It has been observed a culture of PNS bacteria (Rhodobacter shaeroides ZX-5) showed different saturation point understanding and shaking conditions. Although in the standing culture conditions the light saturation point was the usual of 5000 lux, in the skiing culture conditions an increased light capacity was observed at 8000 lux. This increased light saturation point improved the hydrogen production rate by $59 \%$ [23].

The photo-fermentative process can take place in a wide range of light spectrum [1]. However, the existence of infrared light in the light source is very important, because a lack of infrared light source can decrease the biohydrogen production in photo-fermentative systems by $39 \%$ [9].

In direct biophotolytic systems, using green microalgae include the enzyme [Fe-Fe] hydrogenase. This enzyme can convert sunlight to hydrogen with $12-14 \%$ efficiency [9].
However, the maximum values of solar energy conversion efficiency for green microalgae in laboratory experiments do not exceed $3 \%$ [20].

It must be mentioned that $<5 \%$ conversion efficiency in microalgae is needed to achieve a cost-effective photo biological $\mathrm{H}_{2}$ production, provided that the process can be degraded with the production of additional biomass related high value products [20]. It has been reported that $\mathrm{H}_{2}$ production from Chlamydomonas reinhardtii under long wavelength red light $680-700 \mathrm{~nm}$ was greater than under a source of white light [20].

In the indirect biophotolysis process by cyanobacteria the light conversion efficiency level can reach the maximum value of $16.3 \%$. It is also worth mentioning that in this process a better light conversion efficiency can be achieved at low light illumination [9]. It has been reported, that in direct bio photolytic experiment the optimum value of the light source intensity lies between 50 to $200 \mu \mathrm{E} /\left(\mathrm{m}^{2 *} \mathrm{~s}\right)$. Values over the limit of $200 \mu \mathrm{E} /\left(\mathrm{m}^{2 *} \mathrm{~s}\right)$ lead to hydrogen production inhibition and system ineffectiveness [17,21].

\section{$4.6 \mathrm{C} / \mathrm{N}$ ratio}

This parameter affects only the photo-fermentative processes and not the biophotolytic ones. Carbon and nitrogen are elements that appear in significant amounts in the photofermentative systems. The $\mathrm{C} / \mathrm{N}$ ratio is a very significant factor for biohydrogen production by photofermentative system and should be used in an optimized way to maximize the production yields $[11,19]$.

The amount of nitrogen in the system affects the metabolic activity of the enzyme nitrogenase. When the amount of nitrogen is limited, the activity of nitrogenase changes over to hydrogen generation instead of nitrogen fixation. Despite that, nitrogen is a crucial nutrient for the growth of photo-fermentative bacteria. The $\mathrm{C} / \mathrm{N}$ ratio must be adjusted to an optimal level, to limit the nitrogen fixation by nitrogenase while at the same time it will help the bacteria to grow. However, the bacteria growth level must be limited as well, so that they do not inhibit the light penetration into the reactor $[11,13]$.

The inhibition of nitrogen to the nitrogenase enzyme is reversible and the enzyme can be reactivated if ammonium is consumed or removed from the system [13]. After many variations to the $\mathrm{C} / \mathrm{N}$ ratios in photo-fermentative experiments, it was found that the maximum amount of $\mathrm{H}_{2}$ produced was achieved at an optimum $\mathrm{C} / \mathrm{N}$ ratio of 25 using PNSBs [9]. The nitrogen limitation in such systems can be achieved using argon for anaerobic condition instead of molecular nitrogen [13]. 


\subsection{Operation mode}

Biophotolytic processes can take place in batch, continuous or semi-continuous mode. This operation mode is strongly dependent of the photobioreactor selection and design. Because photo-fermentative and biophotolytic processes have not been adapted from industry and they take place most in experiments for research, their usual operation mode is batch [24]. In a batch operation system, the control of the operating conditions becomes easier and the whole process operation is simpler [16]. However, a continuous operating mode is favorable in large-scale operations for practical engineering and designing reasons [15]. In this continuous operating mode that can possibly be adapted by industries a continuous steered tank (CSTR) photobioreactor is preferred, because of the complete mixture between the substrate and the biomass. In CSTR an efficient control of $\mathrm{pH}$ and temperature can also be achieved [15]. An alternative option to the CSTR is the packed bed reactors in which the biomass is mobilized. The main advantage of these reactors is their flexibility, as they can handle large concentrations as well as different types of substrates to produce biohydrogen [16].

\subsection{Nutrients and chemical enhancers}

The supplementation of some chemical substances that act as nutrients can enhance the system's efficiency, because they support the bacterial metabolism growth and activity $[15,19]$. Suitable nutrients are needed, as they lead to proper functioning of the enzymes [9]. Although their enhancing activity, in high concentrations they can be a cause of inhibition [19].

Maybe the most important nutrient for proper growth and metabolism of all the living organisms are vitamins. Microorganisms are not an exception. Addition of vitamins in bacterial medium can prevent deterioration of the culture and increase the bacteria life [2]. The right selection of the proper vitamin for different cultures is very important because it can improve in many ways the systems efficiency and productivity. Some common types of vitamins that are being used especially for many photofermentative systems are nicotinic acid, biotin, vitamin $\mathrm{C}$ and $\mathrm{B}_{1}$ and niacin-amide [2].

Phosphorus can play an important role in energy production in the form of ATP. Apart from this, it can act as a buffer and as an alternative to carbonate [9]. In addition, iron is considered as a main enhancer to biohydrogen producing systems, especially the systems that utilize the enzyme Fe-nitrogenase which contains iron in its structure. The addition of iron (in the form of errors or ferric) in photo-fermentative systems seems to increase the activity of $F$-nitrogenase enzyme. This results into a higher yield and efficiency in the process. However, it is important to mention that the addition of big amounts of iron in such systems may have a negative effect like reduction of light conversion efficiency. This can possibly result into lower yields and efficiency of photo-fermentation, due to its strong light-dependency. Molybdenum can have a similar effect to Mo-nitrogenase enzyme like iron to the Fe-nitrogenase. The production rates and yields of biohydrogen seem to improve with addition of molybdenum in systems that utilize Mo-nitrogenase as a biohydrogen producing enzyme [2].

Nickel is another metal that seems to have enhancing effect in such systems. It is known that nickel is a component element in both hydrogenate and nitrogenous enzymes and the implementation of nickel ions into the bacterial medium can increase the biohydrogen production yield. Nevertheless, it is important to know that the addition of nickel has not always a positive effect, as it depends on the bacterial strain that is being used [2]. Finishing the metal-ions enhancers category, the addition of magnesium in some cases may improve the metabolic process and the growth of bacteria, resulting to an increase in biohydrogen production.

Another chemical substance that can enhance the biohydrogen production in biophotolysis and photofermentation is EDTA (Ethylenediaminetetraacetic acid). Implementation of EDTA in photo-fermentative systems seems to enhance the efficiency due to its chelating agent role [2]. EDTA existence can provide solubility and availability of metal ions (like iron and molybdenum) to the bacterial medium, resulting in improvement of biohydrogen production. Like most of the enhancers that have been discussed the positive effect of EDTA depends on its concentration on the system. Hight concentration of EDTA may inhibit biohydrogen productivity by limiting the availability of metal ions for bacterial growth.

\subsection{Inhibitory factors}

There are many chemical substances and elements that act like contaminants and inhibit the biohydrogen productions processes. Some of them have been discussed previously like iron and molybdenum which can have either a positive or a negative effect, depending on their concentrations and the bacterial medium that is being used in each case.

The most important inhibitor in biophotolysis and photo-fermentation is oxygen. The two enzymes involved in biophotolytic and photo fermentative processes (hydrogenase and nitrogenase) are very sensitive to the presence of oxygen. The conditions in these systems must be anaerobic with oxygen content lower than $0.1 \%$ to maintain efficient hydrogen production [14]. Moreover, hydrogenase which is in the chloroplasts where photosystem II releases $\mathrm{O}_{2}$, is hypersensitive to oxygen. This can be an explanation for the low hydrogen production rates in direct biophotolytic systems [25].

The maintenance of anaerobic conditions can be achieved through three different methods: (i) Enhancement of respiration, (ii) Photochemical reduction of $\mathrm{O}_{2}$ by PSI and (iii) reversible inactivation of $\mathrm{O}_{2}-$ evolution in PSII. Especially, in the process of indirect biophotolysis there can be a separation of hydrogen producing reactions from the oxygen evolving ones leading to maintenance of hydrogen production. The algae cultivation takes place in a small open pond and then these organisms are placed in an anaerobic photobioreactor where they inactivate PSII and induce hydrogenase enzyme [25]. Finally, when sulfur deprived conditions are implemented, the formation of the 
reaction center of PSII (D1 polypeptide chain which contains sulfur) is inhibited. This phenomenon results in fast decline of $\mathrm{O}_{2}$ synthesis and carbon dioxide fixation [26].

Cell immobilization is another important technique that protects the system from contaminants and especially natural harmful factors when the process takes place in an outside area [14]. Finally, in the photo fermentative processes, using wastewaters the existence of some toxic heavy metals is likely. These metals can cause the anaerobic reactor to upset and failure. The most toxic metals that can be most likely found in wastewaters are zinc, nickel, cooper, and cadmium [15].

Table 8 summarizes most chemicals that can act either as improvers or as inhibiting factors in photo fermentative systems.

\section{Specific experiments and biohydrogen yields}

\subsection{Biophotolytic experiments}

A two-step production process was used in which a unicellular green algae Chlamydomonas reinhardtii was studied [27]. During the aerobic phase C. reinhardtii D1 protein mutant strains (D240, D239-40, D240-41) and strain $\mathrm{CC} 124$ are grown photo mixotrophically, under aerobic and sulfur containing conditions. Before reaching the second phase, a lag time is needed to achieve oxygen consumption and starch production. After the lag time, the second phase $\left(\mathrm{H}_{2}\right.$ production phase) follows, which takes place under anaerobic conditions. Light illumination continues for the whole process time, with two different patterns. Starch and light are being utilized and the pretense of the algae, finally leads to biohydrogen production. After studying all the experiment results, it was observed that the protein mutant strains D239-40 and D240-41 were more efficient for $\mathrm{H}_{2}$ under the conditions implemented, compared to the other two protein strains studied. The process conditions and the hydrogen production for these 2 mutant strains are presented in Table 9.

The maximum production of the D239-40 strain was $490 \mathrm{ml} / \mathrm{L}$ at a light intensity of $70 \mu \mathrm{mol}$ photons per $\mathrm{m}^{2} * \mathrm{~s}$, while the maximum production of the D240-41 strain was $388 \mathrm{ml} / \mathrm{L}$ at a light intensity of $70 \mu \mathrm{mol}$ photons per $\mathrm{m}^{2 *} \mathrm{~s}$. In both strains the maximum production was observed with light illumination pattern 2 and a $\mathrm{pH}$ range of $7.5-7.7$ [27].

Another two step biophotolytic process was studied by [15]. During the first phase four green oleaginous microalgae were cultivated under aerobic conditions and during the second phase hydrogen production took place under anaerobic conditions.

The four green oleaginous microalgae cultivated were Chlamydomonas sp., Chlorella sp., Chlorella vulgaris TISTR 8580 and Chlorella protothecoides TISTR 8243. Each microalga was photo autotrophically cultivated in $400 \mathrm{~mL}$ of modified TAP medium with $\mathrm{pH}$ modified to 6.8. The cultivation was performed in a $500 \mathrm{~mL}$ flask. Cultures were incubated at $30{ }^{\circ} \mathrm{C}$, using $\mathrm{CO}_{2}$ in air with a full light illumination at $48 \mathrm{mmol}$ photon per $\mathrm{m}^{2 *} \mathrm{~s}$ light intensity.
Table 8. Effect of chemicals in photo fermentation [2].

Chemicals
Iron
Molybdenum
Nickel
EDTA
Vitamins
Buffer Solutions
Magnesium
Yeast
Ethanol
NaCl
Nano Ti- $0_{2}$
Methanol
Cooper ions
Diphenifide ions

The hydrogen production phase took place in a photobioreactor. This process started when the cultivated cells transferred in a photobioreactor which contained modified TAP medium. In the study many experiments with different conditions were made to compare and find the optimum hydrogen producing conditions from these microalgae. The comparisons were between crude or pure glycerol used as carbon source and sulfur or sulfur deprived conditions. Among these 4 microalgae only Chlorella sp. was able to produce adequate amounts of biohydrogen. For this microalga, it was found that the optimal hydrogen production rate was $11.65 \mathrm{~mL} / \mathrm{L}$. This happened when optimal conditions were implemented. The optimal conditions were crude glycerol used as carbon source with concentration of $16 \mathrm{~g} / \mathrm{L}$, initial $\mathrm{pH} 6.8$ and full light illumination with light intensity of $48 \mathrm{mmol}$ photon per $\mathrm{m}^{2 *} \mathrm{~s}$. The presence of sulfur in the medium found to enhance the biohydrogen production in comparison with sulfur-deprived conditions [18]. 
Table 9. Experimental conditions for optimal $\mathrm{H}_{2}$ production by mutant strains of C. reinhardtii [27].

\begin{tabular}{lllll}
\hline $\begin{array}{l}\text { Protein } \\
\text { Strains }\end{array}$ & $\begin{array}{l}\text { Illumination Pattern } \\
\left(\mu \mathrm{mol} / \mathrm{m}^{2 *} \mathrm{~s}\right)\end{array}$ & $\begin{array}{l}\text { Lag Phase } \\
( \pm 4 \mathrm{~h})\end{array}$ & $\begin{array}{l}\text { Production } \\
\text { time }(\mathrm{h})\end{array}$ & $\begin{array}{l}\mathrm{H}_{2} \text { Production } \\
( \pm 10 \mathrm{ml} / \mathrm{L})\end{array}$ \\
\hline D239-40 & $70 \times 2$ & 34 & 168 & 490 \\
D240-41 & $70 \times 2$ & 34 & 168 & 388 \\
\hline
\end{tabular}

Table 10. Selection of the favorable option based on the experiments' conclusions [10].

\begin{tabular}{lll}
\hline Varying parameters & Options & Favorable option \\
\hline Substrate (Carbon Source) & Acetate-Butyrate & Acetate \\
pH & Acidophilic-Neutral & Acidophilic \\
Anaerobic gas & Nitrogen-Argon & Argon \\
Vitamins & Presence-Absence & Presence \\
Nitrogen Source & AG-MSG & MSG \\
\hline
\end{tabular}

The potential of cyanobacteria strains was studied by Bekzhan D. Kossalbayev and coworkers (2019) [28]. Four strains of cyanobacteria were investigated: Synechocystis sp. PCC 6803, Desertifilum sp. IPPAS B-1220, Synechococcus sp. I12, and Phormidium corium B-26. The cultivation of these strains took place under aerobic conditions with $45 \mu \mathrm{mol}$ photons $/\left(\mathrm{m}^{2}{ }^{\mathrm{s}}\right)$ artificial light supplementation from three sides of the glass tubes, which contained growth media. After the cultivation, the cells were prepared for the hydrogen production stage at ambient temperature with argon taking the place oxygen (for anaerobic conditions). For the light conditions, light was supplied to the cells from one side with an intensity of $30 \mu$ mol photons $/\left(\mathrm{m}^{2 *} \mathrm{~s}\right)$, while shaken at $150 \mathrm{rpm}$.Under these conditions only the Desertifilum sp. IPPAS B-1220 strain was found to produce a significant amount of biohydrogen with the process of direct biophotolysis. The biohydrogen production started after the first day and started decreasing by the end of the 6 th day. The maximum hydrogen production rate was $0.229 \mu \mathrm{mol} \mathrm{H}_{2} / \mathrm{mg} \mathrm{Chl} / \mathrm{h}$ and was noticed at the 166th cultivation hour. In this study the effect of the addition of DCMU (organic substance) was also studied. It was found that DCMU had a double effect on the process, as it both accelerated and enhanced the biohydrogen production. The maximum hydrogen production rate in this case was found after 48 hours and was equal to $0.348 \mu \mathrm{mol} \mathrm{H}_{2} / \mathrm{mg} \mathrm{Chl} / \mathrm{h}$. This experiment proved that the act of DCMU as a photosynthesis inhibitor improved the biohydrogen production process by maintaining the anaerobic conditions [28].

\subsection{Photo-fermentative experiments}

S. Shrikanth and coworkers (2009) [10] studied the photofermentative process for hydrogen production using acetic and butyric acid as primary carbon sources. A mixed photosynthetic culture, that was taken from a lake (from a death of 2-3 feet of the water bodies), was used as inoculum and was enriched with a mix of domestic and dairy wastewaters. These wastewaters were supplemented with vitamin solution for 48 hours, in the presence fluorescent light which had intensity of 4000 lux at the mesophilic temperature of $34^{\circ} \mathrm{C}$. During the experimental process 64 batch experiments took place by varying parameters. The first 32 used acetic acid as a substrate and the other 32 used butyric acid. The varying parameters were presence or absence of vitamin solution, glucose as a co-substrate (initiator), nitrogen source (AG or MSG), the operation $\mathrm{pH}$ $(6-7)$ and finally the gas utilized to create the anaerobic conditions (argon or nitrogen). All the 64 experiments took place at $34^{\circ} \mathrm{C}$ and at a (fluorescent) light intensity of 4000 lux, while agitating at $100 \mathrm{rpm}$. The results of these experiments showed that acetate was a better substrate in comparison with butyrate. Moreover, the optimal $\mathrm{pH}$ for these processes found to be the acidophilic one (6), while the use of glucose as an initiator and the vitamin supplementation led to an improved biohydrogen production. Argon seemed to be a more favorable gas to create anaerobic conditions [10].

Another experiment including acetic or butyric acid as substrates for photo-fermentative biohydrogen production was studied by Raquel Aparecida Loss and co-workers (2012) [29]. The photoheterotrophic culture used for the process, which contained mixed photosynthetic consortia, was cultivated for 3 months using a Winogradsky column, prepared from sediment collected from Brazilian lagoon. The initial $\mathrm{pH}$ was neutral, and temperature was maintained at $30{ }^{\circ} \mathrm{C}$, while the light illumination was $10.25 \mathrm{~W} / \mathrm{m}^{2}$. The concentration of acetate was $30 \mathrm{mmol} / \mathrm{L}$ and the concentration of butyrate was $15 \mathrm{mmol} / \mathrm{L}$. After 10 days of cultivation the biohydrogen yield using acetate as a carbon source was $143.56 \mathrm{ml} / \mathrm{L}$, while using butyrate as a carbon source the biohydrogen yield was $135.41 \mathrm{ml} / \mathrm{L}$ [29]. Both studies showed that acetic acid is a more effective carbon source comparing to butyric acid for photofermentative hydrogen production [10,29].

Efe Boran and coworkers [30], developed a fed-batch process for hydrogen production in a nearly horizontal pilot scale tubular photobioreactor $(V=80 \mathrm{~L})$ using acetate as carbon source and Rhodobacter capsulatus as inoculum. 
Table 11. Yields of biohydrogen based on experiments' results [31].

\begin{tabular}{|c|c|c|c|c|}
\hline Substrate & $\begin{array}{l}\text { Method Operation } \\
\text { Mode }\end{array}$ & Bacteria Microalgae & Conditions & $\begin{array}{l}\text { Biohydrogen } \\
\text { Production }\end{array}$ \\
\hline- & $\begin{array}{l}\text { Two step } \\
\text { Biophotolysis }\end{array}$ & $\begin{array}{l}\text { Chlamydomonas } \\
\text { reinhardtii D239-40 }\end{array}$ & $\begin{array}{l}\text { Light intensity } 70 \mu \mathrm{mol} \\
\text { photons } /\left(\mathrm{m}^{2 *} \mathrm{~s}\right) \text { from } 2 \text { sides } \\
\text { pH } 7.5-7.7,168 \mathrm{~h} \text { of } \\
\text { production }\end{array}$ & $490 \mathrm{ml} / \mathrm{L}$ \\
\hline $\begin{array}{l}\text { Crude } \\
\text { glycerol }\end{array}$ & $\begin{array}{l}\text { Two step } \\
\text { Biophotolysis }\end{array}$ & Chlorella sp. & $\begin{array}{l}\mathrm{pH} 6.8 \text {, light intensity } \\
48 \mu \text { mol photons } /\left(\mathrm{m}^{2} * \mathrm{~s}\right) \text {, } \\
\text { sulfur conditions }\end{array}$ & $11.65 \mathrm{ml} / \mathrm{L}$ \\
\hline- & Direct Biophotolysis & $\begin{array}{l}\text { Desertifilium sp. } \\
\text { IPPAS B-1220 }\end{array}$ & $\begin{array}{l}\text { Argon for anaerobic } \\
\text { conditions, light intensity } \\
30 \mu \text { mol photons } /\left(\mathrm{m}^{2^{*}} \mathrm{~s}\right) \\
\text { shaking at } 150 \mathrm{rpm}, \mathrm{DCMU} \\
\text { addition }\end{array}$ & $\begin{array}{l}\text { Maximum production } \\
\text { rate after } 48 \mathrm{~h} \text { was } \\
0.348 \mu \mathrm{mol} /(\mathrm{mg} \mathrm{Chl} \mathrm{h})\end{array}$ \\
\hline Acetate & Photo-fermentation & $\begin{array}{l}\text { Mixed photosynthetic } \\
\text { consortium }\end{array}$ & $\begin{array}{l}\text { Acidophilic conditions, } \\
\text { argon for anaerobic } \\
\text { conditions, } 34^{\circ} \mathrm{C} \text {, agitation } \\
\text { at } 100 \mathrm{rpm} \text {, light intensity of } \\
14000 \text { lux presence of MSG } \\
\text { and vitamins }\end{array}$ & $\begin{array}{l}\text { The optimal conditions } \\
\text { were studied and not } \\
\text { the actual H2 } \\
\text { production value }\end{array}$ \\
\hline Acetate & Photofermentation & $\begin{array}{l}\text { Mixed photosynthetic } \\
\text { consortium }\end{array}$ & $\begin{array}{l}\text { Neutral } \mathrm{pH}, 30^{\circ} \mathrm{C} \text {, light } \\
\text { intensity } 10.25 \mathrm{~W} / \mathrm{m}^{2} \text {, }\end{array}$ & $143.56 \mathrm{ml} / \mathrm{L}$ \\
\hline Acetate & $\begin{array}{l}\text { Photofermentation, } \\
\text { fed batch in pilot } \\
\text { scale tubular } \\
\text { photobioreactor } \\
(80 \mathrm{~L})\end{array}$ & $\begin{array}{l}\text { Rhodobacter } \\
\text { capsulatus }\end{array}$ & $\begin{array}{l}\text { Outdoor conditions, } \\
\text { mesophilic temperature, } \mathrm{pH} \\
8 \text { maintained into a } \\
\text { greenhouse, nitrogen, and } \\
\text { argon for anaerobic } \\
\text { condition, combined } \\
\text { artificial and natural light } \\
\text { illumination, 30-day process }\end{array}$ & $0.31 \mathrm{~mol} /\left(\mathrm{m}^{3} \mathrm{~s}\right)$ \\
\hline Acetate & $\begin{array}{l}\text { Batch } \\
\text { photofermentation }\end{array}$ & $\begin{array}{l}\text { Rhodobacter } \\
\text { capsulatus DSM1710 }\end{array}$ & $\begin{array}{l}\mathrm{pH} 6.4,30^{\circ} \mathrm{C} \text {, argon for } \\
\text { anaerobic conditions, light } \\
\text { intensity } 263.6 \mathrm{~W} / \mathrm{m}^{2} \\
\text { sodium glutamate as } \\
\text { nitrogen source }\end{array}$ & $1.04 \mathrm{mmol} /(\mathrm{L} \mathrm{h})$ \\
\hline
\end{tabular}

The process took place during winter in outdoor conditions and to keep temperature in a mesophilic range, the photobioreactor was placed inside a greenhouse. The modified medium used for biohydrogen production was taken from Biebl and Phennig (1981), which contained the carbon source $(40 \mathrm{mM}$ acetate) and the nitrogen source (2 mM Na-glutamate) for a final $\mathrm{C} / \mathrm{N}$ ratio equal to 45 . Argon was supplemented in the photobioreactor for creating anaerobic conditions. Artificial light source was supplemented from two sides of the reactor with a light intensity of $500 \mathrm{~W}$ each, during the exponential phase. After the end of exponential phase, artificial light supplementation stopped, and sunlight used as the only source. The process operated for 30 days, and the temperature levels observed to be between 10 and $35{ }^{\circ} \mathrm{C}$. The average $\mathrm{pH}$ was above the neutral level around 8. Light illumination varied because sunlight used as source instead of a fully-control artificial source. It was observed that when light illumination showed an average value below 10
kLux at the surface, the biohydrogen productivity was decreased. Light intensity values above $10 \mathrm{kLux}$ led to satisfying hydrogen production. This is a proof that biohydrogen production can take place in winter conditions by using sun as the only light source. Although acetic acid was fully consumed, $16 \%$ of it was utilized to produce biohydrogen. The biohydrogen molar productivity that was observed was equal to $0.31 \mathrm{~mol} /\left(\mathrm{m}^{3} * \mathrm{~s}\right)$. This study presented a pilot scale effort to produce biohydrogen though photo-fermentation, using a tubular $80 \mathrm{~L}$ photobioreactor [30].

Melih Can Akman and coworkers [31] investigated the effects of some major parameters on biohydrogen production via photo-fermentation by PNS bacteria in batch photobioreactors. These parameters were the light intensity and substrate and biomass concentrations in the reactor. The analysis was made using by the Response Surface Methodology, where both individual and interactive effects of these parameters were investi- 
Table 12. Typical microalgal biohydrogen productivity.

\begin{tabular}{|c|c|c|c|c|c|}
\hline Microalgae strain & Light intensity & $T\left({ }^{\circ} \mathrm{C}\right)$ & $\mathrm{pH}$ & Biohydrogen production rate & References \\
\hline $\begin{array}{l}\text { Chlamydomonas } \\
\text { MGA } 161\end{array}$ & $115 \mu \mathrm{E} / \mathrm{m}^{2 / \mathrm{s}}$ & 30 & 8 & $4.48 \mathrm{ml} /\left(\mathrm{L}^{*} \mathrm{~h}\right)$ & {$[21]$} \\
\hline Chlorella reinhardtii & $100 \mu \mathrm{E} / \mathrm{m}^{2} / \mathrm{s}$ & - & - & $2.8-2.9\left(\mathrm{~L}^{*} \mathrm{~h}\right)$ & {$[9]$} \\
\hline $\begin{array}{l}\text { Platymonas } \\
\text { subcordiformis }\end{array}$ & $160 \mu \mathrm{E} / \mathrm{m}^{2} / \mathrm{s}$ & - & - & $2.7 \mathrm{ml} /\left(\mathrm{L}^{*} \mathrm{~h}\right)$ & {$[16]$} \\
\hline $\begin{array}{l}\text { Chlamydomonas } \\
\text { reinhardtii CC-124 }\end{array}$ & $100 \mu \mathrm{E} / \mathrm{m}^{2} / \mathrm{s}$ & $28-30$ & 7 & $2.2 \mathrm{ml} /\left(\mathrm{L}^{*} \mathrm{~h}\right)$ & {$[21]$} \\
\hline $\begin{array}{l}\text { Chlamydomonas } \\
\text { reinhardtii CC-124 }\end{array}$ & $\begin{array}{l}140 \mu \text { mol photons } /\left(\mathrm{m}^{2} * \mathrm{~s}\right) \\
- \text { both sides }\end{array}$ & 28 & 7.2 & $7.5 \mathrm{ml} /\left(\mathrm{L}^{*} \mathrm{~h}\right)$ & {$[20]$} \\
\hline $\begin{array}{l}\text { Chlorella } \\
\text { sorokiniana Ce }\end{array}$ & $120 \mu \mathrm{E} / \mathrm{m}^{2} / \mathrm{s}$ & - & - & $1.92 \mathrm{ml} /\left(\mathrm{L}^{*} \mathrm{~h}\right)$ & {$[16]$} \\
\hline $\begin{array}{l}\text { Chlamydomonas } \\
\text { reinhardtii } 137 \mathrm{c}\end{array}$ & $110 \mu \mathrm{E} / \mathrm{m}^{2} / \mathrm{s}$ & 25 & 7.2 & $2.5 \mathrm{ml} /\left(\mathrm{L}^{*} \mathrm{~h}\right)$ & {$[21]$} \\
\hline $\begin{array}{l}\text { Chlorella sp. strain } \\
\text { Pt6 }\end{array}$ & $120-140 \mu \mathrm{E} * \mathrm{~m}-2 * \mathrm{~s}-1$ & - & - & $0.8 \mathrm{ml} /\left(\mathrm{L}^{*} \mathrm{~h}\right)$ & {$[7]$} \\
\hline $\begin{array}{l}\text { Chlamydomonas } \\
\text { reinhardtii CC-1036 }\end{array}$ & $120 \mu \mathrm{mol}$ photons $/\left(\mathrm{m}^{2} * \mathrm{~s}\right)$ & $27-29$ & 7 & $9.2 \mathrm{ml} /\left(\mathrm{L}^{*} \mathrm{~h}\right)$ & {$[20]$} \\
\hline
\end{tabular}

gated. The study resulted to an optimum value of these 3 parameters for maximum biohydrogen yield. The bacterial strain that was utilized in this experiment was Rhodobacter capsulatus DSM 1710 and was cultivated heterotrophically in a modified Biebl and and Pfenning medium. Acetate was used as carbon source, while sodium glutamate was used as nitrogen source. For the hydrogen producing medium there was used again acetate and sodium glutamate in 3 different experiments with different concentrations $(20 \mathrm{mM}, 40 \mathrm{mM}, 60 \mathrm{mM}$ for acetate and $1.33 \mathrm{mM}, 2.67 \mathrm{mM}, 4 \mathrm{mM}$ for sodium glutamate respectively) each time, while the $\mathrm{C} / \mathrm{N}$ ratio maintained constant at 15 . The light intensity values that were implemented in 3 different experiments were 100,200 and $300 \mathrm{~W} / \mathrm{m}^{2}$, while the 3 different VSS concentrations were $0.05 \mathrm{~g} / \mathrm{L}, 0.2 \mathrm{~g} / \mathrm{L}$ and $0.35 \mathrm{~g} / \mathrm{L}$. For all the experiments the $\mathrm{pH}$ was adjusted to 6.4 and was maintained between 6.8 and 7.4 for the whole processing time, while the temperature in the photobioreactor was maintained at $30{ }^{\circ} \mathrm{C}$. The gas used for anaerobic conditions was argon. After performing these 9 experiments RSM-Box Behnken design method was used to optimize the 3 major parameters, using the results from the previous experiments. These 3 major parameters were the individual variables in the mathematical model, while biohydrogen production rate was the response. The results of the solution of the optimization model, showed that maximum bioH $_{2}$ production could be achieved at $35.35 \mathrm{mM}$ acetate concentration, $0.27 \mathrm{~g}$ VSS/L and $263.6 \mathrm{~W} / \mathrm{m}^{2}$ light intensity. This maximum biohydrogen production rate was calculated at $1.04 \mathrm{mmol} /\left(\mathrm{L}^{*} \mathrm{~h}\right)$. This was one of the few papers that investigated the combined effect of some key factors in photo-fermentation processes using modeling and optimization of the process [31].
A summary of the experiments presented above is shown in Table 11, including information about bacterial strain, experimental method, conditions and biohydrogen production.

\subsection{Photo biohydrogen yields}

An analysis of the literature database was made, and tables have been made to demonstrate the productivity of microalgae, cyanobacteria and PNS bacteria in varying conditions. The most notable conditions for each experiment are also presented, to show the effectiveness of the microorganism's dependence on different conditions. Especially, research regarding waste utilization through photo-fermentation has been carried out, to emphasize the application ability of this method in waste environment.

Table 12 shows that the production rate of biohydrogen produced using microalgal strains varies from 0.8 to $9.2 \mathrm{~mL} /\left(\mathrm{L}^{*} \mathrm{~h}\right)$. The strain called Chlamydomonas reinhardtii CC-1036 found to be more efficient in terms of biohydrogen production as its production rate is $9.2 \mathrm{~mL} /$ $\left(\mathrm{L}^{*} \mathrm{~h}\right)$. Conditions implemented are found to be mild (temperature 25-30 OC and $\mathrm{pH}$ 7-8) while the light intensity ranges from $100-160 \mu \mathrm{E} / \mathrm{m}^{2} * \mathrm{~s}$.

Table 13 presents extensive amount of data found in literature, regarding production rates and conditions during hydrogen production from a wide variety of cyanobacteria. Anabaena cylindrica $\left(30 \mathrm{ml} /\left(\mathrm{L}^{*} \mathrm{~h}\right)\right)$, Gloeocapsa alpicola $(25 \mathrm{~mL} / \mathrm{h})$, Cyanothese sp. ATCC 51142 $(465 \mu \mathrm{mol} /(\mathrm{mg} \mathrm{Chl} * \mathrm{~h}))$ are the cyanobacterial strains that present the most notable biohydrogen production rates. The light illumination shows a wide variety of intentions, some cyanobacteria require low light intensities and some others notably higher. 
Table 13. Cyanobacteria biohydrogen productivity according to literature.

\begin{tabular}{|c|c|c|c|c|}
\hline Cyanobacteria strain & Light Intensity & $\mathrm{T}\left({ }^{\circ} \mathrm{C}\right)$ & $\begin{array}{l}\text { Biohydrogen production } \\
\text { yield }\end{array}$ & References \\
\hline Cyanothese sp. ATCC 51142 & $30 \mu \mathrm{Em}^{2} / \mathrm{s}$ & - & $465 \mu \mathrm{mol} /(\mathrm{mg} \mathrm{Chl} * \mathrm{~h})$ & {$[28]$} \\
\hline Synechocystis strain M55 & - & - & $200 \mathrm{nmol} /\left(\mathrm{mg} \mathrm{Chl}{ }^{*} \min \right)$ & {$[28]$} \\
\hline Anabaena PCC7 120 & $456 \mu \mathrm{E} / \mathrm{m}^{2} / \mathrm{s}$ & - & $14.9 \mathrm{ml} / \mathrm{h}$ & {$[9]$} \\
\hline Arthrospira sp. PCC 8005. & $40 \mu \mathrm{E} / \mathrm{m} 2 / \mathrm{s}$ & $30^{\circ} \mathrm{C}$ & $5.91 \mathrm{ml} /\left(\mathrm{L}^{*} \mathrm{~h}\right)$ & {$[21]$} \\
\hline Synechocystis sp. PCC 6803 & $300 \mu \mathrm{mol}$ photons $\mathrm{m}^{2} / \mathrm{s}$ & - & $190 \mathrm{nmol} /(\mathrm{mg} \mathrm{Chl} * \min )$ & {$[28]$} \\
\hline Gloeocapsa alpicola & $165 \mu \mathrm{E} / \mathrm{m}^{2} / \mathrm{s}$ & - & $25 \mathrm{ml} / \mathrm{h}$ & [9] \\
\hline Anabaena Cylindrica & $140 \mu \mathrm{E} * \mathrm{~m}-2 * \mathrm{~s}-1$ & - & $30 \mathrm{ml} /\left(\mathrm{L}^{*} \mathrm{~h}\right)$ & {$[7]$} \\
\hline Synechococcus sp. Miami BG 043511 & $150 \mu \mathrm{E} / \mathrm{m}^{2} / \mathrm{s}$ & 30 & $220 \mu \mathrm{mol} /(\mathrm{mg} \mathrm{Chl} * \mathrm{~h})$ & {$[28]$} \\
\hline Anabaena variabilis ATCC 29413 & $110-120 \mu \mathrm{E} / \mathrm{m} 2 / \mathrm{s}$ & 30 & $14.9 \mathrm{ml} /(\mathrm{L} * \mathrm{~h})$ & {$[21]$} \\
\hline Anabaena Azollae & $140 \mu \mathrm{E} / \mathrm{m}^{2} / \mathrm{s}$ & - & $13 \mathrm{ml} /\left(\mathrm{L}^{*} \mathrm{~h}\right)$ & {$[21]$} \\
\hline Synechococcus sp. StrainH-1 & $100 \mu \mathrm{E} / \mathrm{m}^{2} * \mathrm{~s}$ & - & $0.9 \mathrm{ml} /(\mathrm{L} * \mathrm{~h})$ & {$[16]$} \\
\hline Anabaena $A M C 414$ & $220 \mu \mathrm{E} * \mathrm{~m}^{2}{ }^{2} * \mathrm{~s}-1$ & - & $14.9 \mathrm{ml} /\left(\mathrm{L}^{*} \mathrm{~h}\right)$ & [7] \\
\hline Anabaena Variabilis & $353 \mu \mathrm{E} / \mathrm{m}^{2} / \mathrm{s}$ & - & $20 \mathrm{ml} / \mathrm{h}$ & {$[9]$} \\
\hline Synechocystis sp. PCC 6308 & $20-30 \mu \mathrm{E} / \mathrm{m}^{2 / \mathrm{s}}$ & - & $3.1 \mu \mathrm{l} /(\mathrm{mg} \mathrm{Chl} * \mathrm{~h})$ & {$[28]$} \\
\hline Chroococcidiopsis thermalis CALU758 & $70 \mu \mathrm{E} / \mathrm{m}^{2} / \mathrm{s}$ & 26 & $4.03 \mathrm{ml} /\left(\mathrm{L}^{*} \mathrm{~h}\right)$ & {$[21]$} \\
\hline Synechocystis sp. PCC 6803 & $90 \mu \mathrm{E} / \mathrm{m}^{2} / \mathrm{s}$ & 30 & $18.4 \mu \mathrm{l} /(\mathrm{mg} \mathrm{Chl} * \mathrm{~h})$ & {$[28]$} \\
\hline Spirulina Platensis & $8 \mathrm{~W} / \mathrm{m}^{2}$ & & $4.032 \mathrm{ml} /\left(\mathrm{L}^{*} \mathrm{~h}\right)$ & {$[17]$} \\
\hline Oscillatoria sp. Miami BG7 & - & - & $260 \mu \mathrm{mol} /(\mathrm{mg} \mathrm{Chl} * \mathrm{~h})$ & {$[28]$} \\
\hline Synechococcus PCC 6307 & $20-30 \mu \mathrm{E} / \mathrm{m}^{2} / \mathrm{s}$ & - & $0.47 \mu \mathrm{l} /(\mathrm{mg} \mathrm{Chl} * \mathrm{~h})$ & {$[28]$} \\
\hline
\end{tabular}

When it comes to comparing the data in Tables 12 and 13 , some remarkable points can be mentioned. Firstly, cyanobacteria show significantly higher production efficiency than the other bio photolytic microorganisms studied, the microalgae. Furthermore, many cyanobacterial strains demand low light intensity (compared to microalgae) and thus significantly lower energy demands. Comparisons about temperature conditions can't be made due to lack of this kind of data regarding cyanobacteria.

Table 14 presents different PNS bacteria strains and the substrates they utilize to produce biohydrogen through a photo-fermentative way. Data about conditions implemented, types of process used and biohydrogen production yields are shown, too. It can be observed that a wide variety of organic compounds can be used as substrates such as glucose, malate, butyrate, glycerol, etc. The highest production yield is achieved by Rhodobacter sphaeroides KD131 when hexose is used as substrate (batch process). The biohydrogen yield is $8.35 \mathrm{~mol} / \mathrm{mol}$ hexose. It must be mentioned that Rhodopseudomonas palustris and Rhodobacter sphaeroides KD131 can produce photo-fermentative biohydrogen at continuous process and the hydrogen yields are $6 \mathrm{~mol} / \mathrm{mol}$ glycerol and $2.3 \mathrm{~mol} / \mathrm{mol}$ succinate, respectively. This is important because continuous mode is more efficient but it far more difficult to be implemented than batch mode, which is commonly used. The temperature and $\mathrm{pH}$ conditions are mild. Temperature ranges from 30 to $35^{\circ} \mathrm{C}$ and $\mathrm{pH}$ from 7 to 8 .

In Table 15 data about PNS bacteria are shown, as well. However, the main difference with the previous table is that biohydrogen production rates are mentioned instead of yields. Many different types of PNS bacteria present impressive ability for efficient hydrogen production. The highest production rate of $130 \mathrm{~mL} /\left(\mathrm{L}^{*} \mathrm{~h}\right)$ is produced by R. capsulatus ST410, while malate is used as substrate. It is notable that R. sphaeroides ZX-5 can utilize many different types of organic substrates and this can lead to high production rates $\left(40-118 \mathrm{~mL} /\left(\mathrm{L}^{*} \mathrm{~h}\right)\right)$. Thus, $R$. sphaeroides $Z X-5$ is found to be one of the most preferable and efficient PNS bacteria for photofermentation. In this table, data regard photo-fermentative production only in batch operation.

A big advantage of photo-fermentation is that this method can utilize different types of waste to produce biohydrogen. In Table 16 database about bacterial strains contained in the wastes, conditions during fermentation and biohydrogen production yields can be found. It is admirable that many different types of wasted can be used as substrate during photo-fermentation. Sugar refinery wastewater, olive mill wastewater and sugar beet molasses blackstrap molasses show high efficiency because when these wastes are used as substrate notable hydrogen production yield can be achieved. Photo-fermentation using sugar refinery wastewater and brewery wastewater can be performed as a continuous process. This is important because production at a large(industrial) scale can only be performed continuously. Temperature and $\mathrm{pH}$ (according to available data) can be characterized as mild (similar with the previous tables), while the light intensity ranges mostly from 4000 to 154000 lux. 


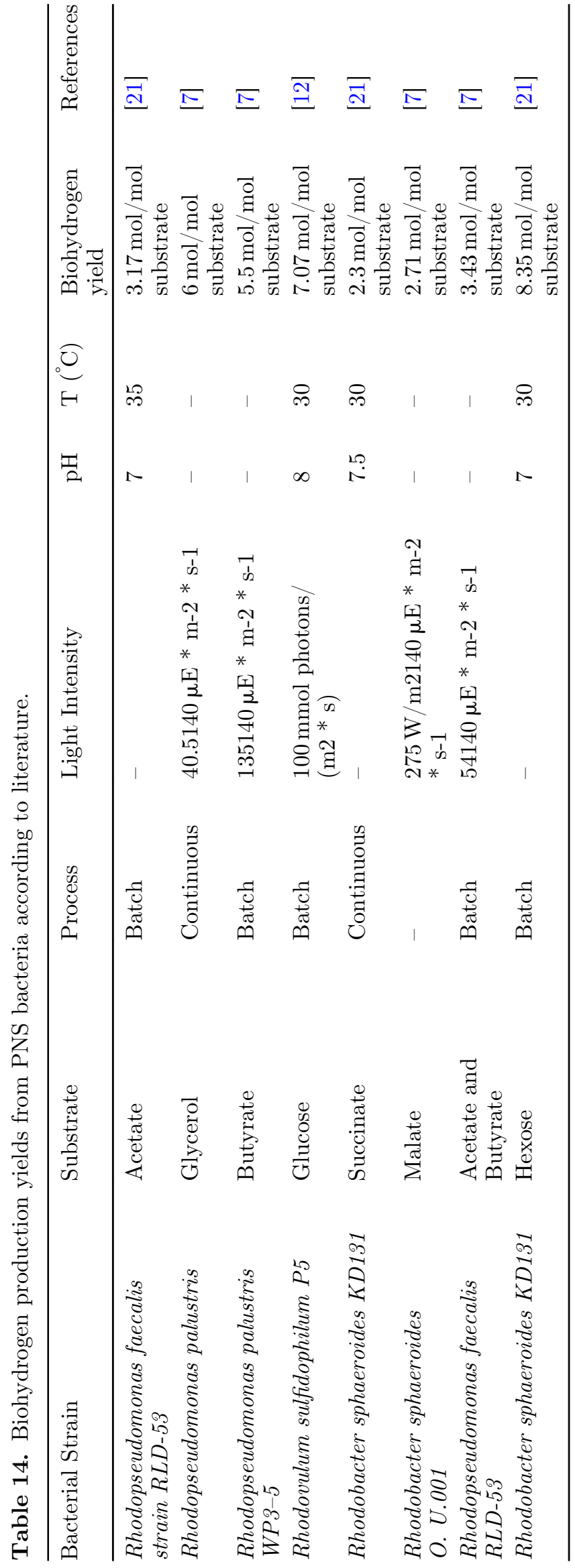

\section{Discussion}

\subsection{Biophotolysis vs photo-fermentation}

Based on the detailed research, which was presented above, it can be said that both photo-fermentation and biophotolysis seem to have strengths and weaknesses.

Both methods aim to solve the challenging problem regarding photobiological hydrogen production, which is an important research topic since biohydrogen is considered as a clean energy source, in contrast with hydrogen produced from methane or gasification (most common methods).

As both are bio-processes they have a lot in common. For example, both biophotolysis and photo-fermentation take place under anaerobic conditions, as they both utilize the same biohydrogen producing enzymes (nitrogenase and hydrogenase). As it has been discussed earlier the gas used to achieve these anaerobic conditions is an optimization factor.

Moreover, both methods need light source to produce biohydrogen and they take place into photobioreactors.

None of two methods have been applied in industrial scale (because they still have low light conversion efficiencies) [21], but they are still performed only at laboratory scale as batch processes.

Although both methods have some features in common, they also have some differences. Biophotolysis needs water to produce hydrogen, in contrast with photo-fermentation which uses organic source (including wastewaters and food wastes). Another difference is that they utilize different microorganism species. Photo-fermentation mostly uses PNS bacteria, while biophotolysis uses cyanobacteria as well as microalgae.

Biophotolysis has a high theoretical efficiency and that it helps the environment in many ways, so it can be assumed that biophotolysis can be applied in industrial scale, if some main bottlenecks can be surpassed. More specifically, biophotolysis uses water. Water can be converted directly into biohydrogen via biophotolytic processes. Biophotolytic processes use carbon dioxide in their photosynthetic cycle to produce energy. Biophotolysis can contribute to the nitrogen fixation in the atmosphere by utilizing the nitrogenase enzyme. Thus, It becomes obvious that biophotolysis can play an important role in the environmental crisis that humanity faces. Despite high efficiencies have not been observed in practice, the theoretical thermodynamic efficiency that the process can reach is high. Finally, the mechanism of the process is simple and inexpensive, while microorganisms grow in environments containing simple minerals [14]. One of biophotolysis drawbacks is the high energy cost, as there is a requirement for high artificial light supplementation. Artificial light is much more efficient than natural, because of its stability, 24-hour availability and possible intensity adjustments considering the needs. Another bottleneck of the process is the production of oxygen in the system though photosynthesis, which is an inhibitory factor to the hydrogenase enzyme functionality. As the process starts no oxygen appears in the system (anaerobic conditions). However, as hydrogen gets produced from the system, 
Table 15. Biohydrogen production rates from PNS bacteria according to literature.

\begin{tabular}{|c|c|c|c|c|c|}
\hline Bacterial Strain & Substrate & Process & Light Intensity & $\begin{array}{l}\text { Biohydrogen } \\
\text { production rate }\end{array}$ & References \\
\hline Rhodopseudomonas sp & Acetate & Batch & - & $25.2 \mathrm{ml} /\left(\mathrm{L}^{*} \mathrm{~h}\right)$ & [23] \\
\hline $\begin{array}{l}\text { Rhodobacter sphaeroides } \\
\text { O.U. } 001\end{array}$ & $\begin{array}{l}\text { Malate, Acetate } \\
\text { and Butyrate }\end{array}$ & - & - & $24 \mathrm{ml} /\left(\mathrm{L}^{*} \mathrm{~h}\right)$ & {$[21]$} \\
\hline $\begin{array}{l}\text { Rhodopseudomonas } \\
\text { palustris WP3-5 }\end{array}$ & Butyric acid & Batch & $135 \mu \mathrm{E} * \mathrm{~m}^{-2} * \mathrm{~s}^{-}{ }^{1}$ & $24.9 \mathrm{ml} /\left(\mathrm{L}^{*} \mathrm{~h}\right)$ & {$[7]$} \\
\hline R. sphaeroides $Z X-5$ & Lactate & Batch & - & $103 \mathrm{ml} /\left(\mathrm{L}^{*} \mathrm{~h}\right)$ & {$[23]$} \\
\hline $\begin{array}{l}\text { Rhodobacter sphaeroides } \\
\text { O.U. } 001\end{array}$ & Malate & - & $200 \mathrm{~W} / \mathrm{m}^{2}$ & $20 \mathrm{ml} /\left(\mathrm{L}^{*} \mathrm{~h}\right)$ & {$[17]$} \\
\hline R. capsulata & Acetate & Batch & - & $18.72 \mathrm{ml} /\left(\mathrm{L}^{*} \mathrm{~h}\right)$ & {$[23]$} \\
\hline R. sphaeroides $Z X-5$ & Butyrate & Batch & - & $118 \mathrm{ml} /\left(\mathrm{L}^{*} \mathrm{~h}\right)$ & [23] \\
\hline $\begin{array}{l}\text { Rhodopseudomonas } \\
\text { faecalis } R L D-53\end{array}$ & Acetate & Batch & $150 \mathrm{~W} / \mathrm{m}^{2}$ & $36.60 \mathrm{ml} /\left(\mathrm{L}^{*} \mathrm{~h}\right)$ & {$[7]$} \\
\hline $\begin{array}{l}\text { Rhodobacter sphaeroides } \\
Z X-5\end{array}$ & Malate & Batch & $68 \mu \mathrm{E} * \mathrm{~m}^{2}{ }^{2} * \mathrm{~s}^{1}$ & $102.33 \mathrm{ml} /\left(\mathrm{L}^{*} \mathrm{~h}\right)$ & {$[7]$} \\
\hline R. sphaeroides $R V$ & Lactate & Batch & - & $62.5 \mathrm{ml} /\left(\mathrm{L}^{*} \mathrm{~h}\right)$ & {$[23]$} \\
\hline $\begin{array}{l}\text { Rhodobacter capsulatus } \\
\text { ST410 }\end{array}$ & Malate & - & $66 \mathrm{~W} / \mathrm{m}^{2}$ & $100 \mathrm{ml} /\left(\mathrm{L}^{*} \mathrm{~h}\right)$ & {$[17]$} \\
\hline R. capsulatus ST410 & Malate & Batch & - & $130 \mathrm{ml} /\left(\mathrm{L}^{*} \mathrm{~h}\right)$ & {$[23]$} \\
\hline R. sphaeroides $Z X-5$ & Sucrose & Batch & - & $40 \mathrm{ml} /\left(\mathrm{L}^{*} \mathrm{~h}\right)$ & [23] \\
\hline $\begin{array}{l}\text { Rhodopseudomonas } \\
\text { palustris CQK } 01\end{array}$ & Glucose & Batch & $67.5 \mu \mathrm{E} * \mathrm{~m}^{-2}{ }^{2} \mathrm{~s}^{1}$ & $38.9 \mathrm{ml} /\left(\mathrm{L}^{*} \mathrm{~h}\right)$ & {$[7]$} \\
\hline R. sphaeroides $Z X-5$ & Succinate & Batch & - & $108 \mathrm{ml} /\left(\mathrm{L}^{*} \mathrm{~h}\right)$ & [23] \\
\hline $\begin{array}{l}\text { Rhodospirillum rubrum } \\
\text { UR2 }\end{array}$ & Succinate & $\begin{array}{l}\text { Fed-batch } \\
\text { culture }\end{array}$ & - & $20.67 \mathrm{ml} /\left(\mathrm{L}^{*} \mathrm{~h}\right)$ & [23] \\
\hline
\end{tabular}

oxygen gets produced as well, due to the biophotolytic reaction stoichiometry. This means that the more hydrogen that is produced, the more oxygen appears in the system consulting in inhibition of the hydrogenase enzyme and decrease in system's efficiency. The production rates reported in literature show that biophotolysis is not feasible yet due to the low productivity yields, however if some of the above bottlenecks get surpassed (more discussion in Sect. 7), biophotolysis can be a realistic option for sustainable biohydrogen production.

Regarding photo-fermentation, the PNS bacteria can produce hydrogen in a wide range of light energy, which is an important advantage of the method in comparison with biophotolysis [32]. Another benefit of this process is the fact that it converts the carbon source used as substrate, completely [33]. This carbon source can be derived from many different types of wastes. Another difference with biophotolysis that can be an imposing factor for photofermentation, is the fact that the fact that in photofermentation there is no photosynthesis taking place, so there is no oxygen production. As a result of this phenomenon the anaerobic conditions can be maintained more easily in contrast with photo-fermentation [34]. In addition, photo-fermentation has the same environmental effect with biophotolysis fixing nitrogen from the atmosphere. It was also observed (taking under consideration the tables from Sect. 5) that comparing to biophotolysis, photo-fermentation seems to be a more biohydrogen productive method, due to its high yields. Despite the advantages that were presented above, photo-fermentation seems to have some major limitations and disadvantages. Some of these imitations can be surpassed, some other need more research and investment to establish photo-fermentation as a sustainable biohydrogen producing method. In the photo-fermentative process artificial light is more favorable (comparing to sunlight) for the same reasons that have been discussed about biophotolysis. In addition, the light energy demands for photofermentation are higher than the ones of biophotolysis [34]. This is an important economic disadvantage that questions the methods sustainability. As a contributor to this problem, the light conversion efficiencies that have been observed practically are low [32]. This results to practically low hydrogen yields, something that inhibits the application of this method in industrial scale. Like biophotolysis, the photo-fermentation studies were taking place mainly in batch processes, a limiting factor for extended biohydrogen production via this method. Moreover, the photobioreactors that are widely used both for the two methods are rare and expensive, as they need a large surface area exposed to the light source [14].

In conclusion, both methods have their pros and cons, however it is realistic to say that they can be considered as a huge breakthrough in hydrogen production and overall 


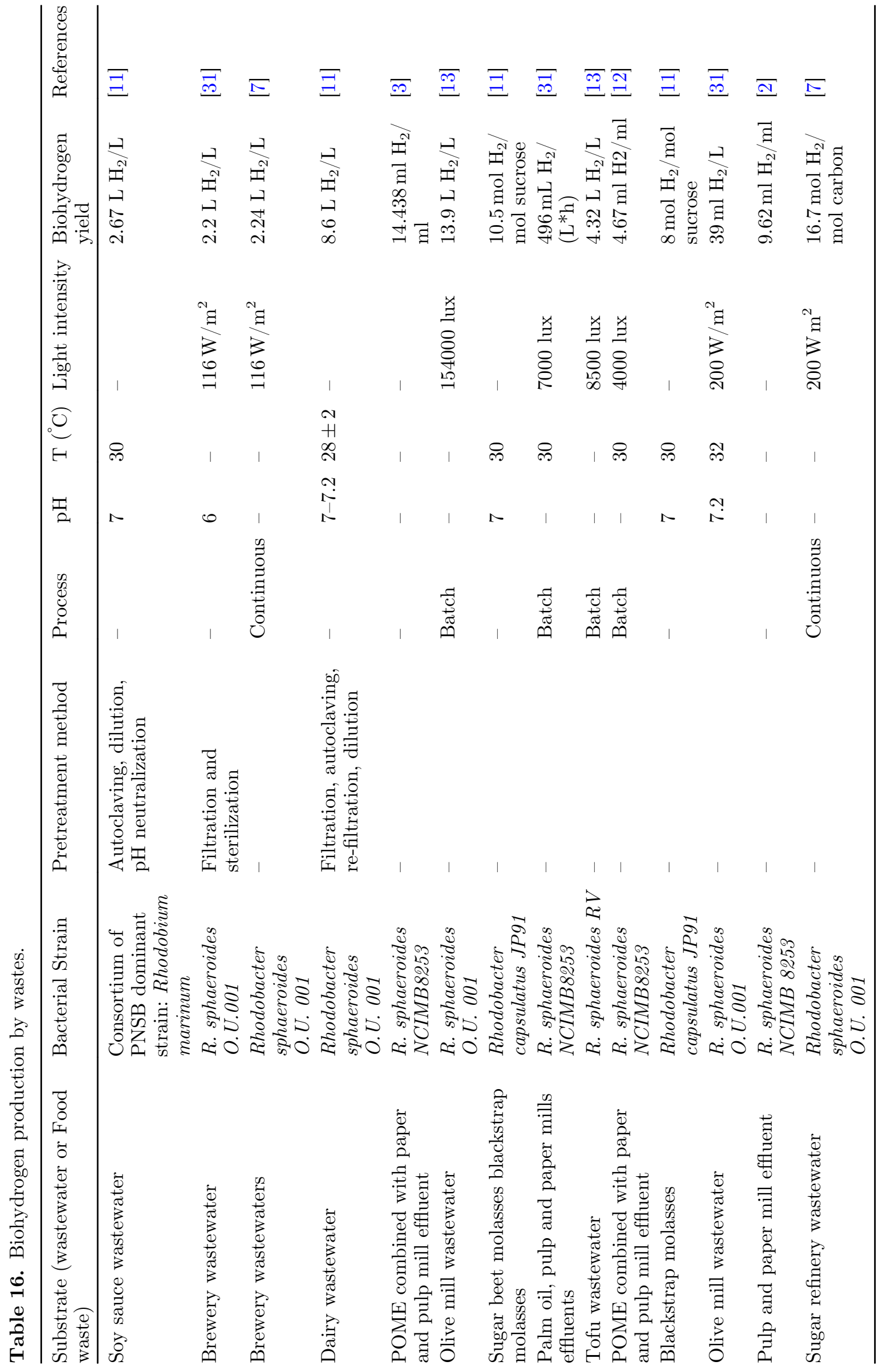


energy production. Although both methods can be contributors in solving the environmental challenges of the 21st century, at multiple levels, efforts are still needed to be made in order to increase the methods efficiencies and to overcome some of the bottlenecks.

It should be mentioned they can offer important economic benefits, depending on the raw materials they process (wastes and abundant in the nature microorganisms), the energy needed (abundant sunlight) and the high value product that is being produced (hydrogen's importance has been discussed in introduction).

Nevertheless, both methods (bio photolysis and photofermentation) are not yet economically feasible due to the factors discussed. The only effort for industrialization is taking place in Taiwan. This effort is a 20-year model decided in 3 phases [1]. thus, there is need for further R\&D to establish these processes at higher TRL (Technology Readiness Level) and large industrial scale.

\subsection{Future prospects}

Both photo-fermentation and biophotolysis offer many advantages, however their transfer at the industrial scale needs more R\&D efforts. The advantages that these hydrogen producing methods seem to provide, have opened the way for R\&D strategies to solve the consequent problems that have been discussed above. The major strategies include the optimization of photobioreactors design, the combination of photo-fermentation with dark-fermentation to increase the process efficiency and finally the use of synthetic biology, genetic and metabolic engineering to alter the metabolic pathways of these processes.

Metabolic and genetic engineering are one pf the main solutions for. Improving future biohydrogen production through altering the metabolic pathways of photofermentation and bio photolysis. One of the strategies is being focused is the gene manipulation through disruption of endogenous genes [24].

An innovative approach for enhancing the process of photo-fermentation seems to be the utilization of a combination of green microalgae and photosynthetic bacteria. Implementing this approach, the metabolic integration showed improvement, as green microalgae generated organic carbon from water and carbon dioxide, whereas the nitrogenase enzyme of the photosynthetic bacteria generated organic nitrogen. The improvement of the metabolic integration resulted in higher biohydrogen production yields [19].

Genetic engineering and biotechnology have developed solving solutions to the oxygen inhibition problem that results in low biohydrogen yields. Sustainable $\mathrm{H}_{2}$ production might be obtained both in algae and cyanobacteria by engineering an oxygen tolerant hydrogenase enzyme. This can result in replacing the native oxygen sensitive hydrogenase with a strong oxygen tolerant material enzyme and may lead to improvement of the biophotolytic hydrogen production yields [25].

Regarding biophotolysis, there is a demand in low partial oxygen pressure to allow the activation of the enzymes involved in the bioprocess. A strategy to achieve this is developing and using substance or conditions that absorb oxygen [9]. For example, sulfur depriving conditions inhibit formation of the sulfur containing D1 polypeptide chain which results in fast decline of oxygen generation into the system [26].

It is also worth mentioning that there has been some advance in the microorganism's cultivation methods. For example, it has been reported that substrate utilization from microalgae can be increased by supplementing the HUP1 (hexose uptake protein) from chlorella kessleri in some microalgae strains. This aims to enrich the cultivation which now is heterotrophically grown in the dark. The existence of low concentrations of glucose was found to increase the biohydrogen production capacity [26].

Another trend to make the process more sustainable in an economical step point, is the use of mixed consortia of photobiological bacteria, for better utilization of the solar spectrum [17]. Moreover, a new hybrid photosynthetic organism, which will contain a normal PSII (chlorophyll a) and a bacterial chlorophyll containing PSI, can be considered as an effective future prospect for sustainable biohydrogen production via bio photolysis. This organism will have the ability to absorb light energy at wavelengths accessible to both bacterial-chlorophyll a and chlorophyll a, resulting to increase the light source spectrum that can be utilized. Another strategy is creating strains with smaller size antennas that will lead to augmentation of the efficiency of the photosynthetic process [33].

As it has been stated earlier, it is significant to develop and improve the design of continuous photobioreactors to apply biophotolysis or photo-fermentation by the industry [33]. Continuous mode is far more favorable than batch, because complete mixing is being achieved while the control of major parameters is becoming easy (for example $\mathrm{pH}$ and temperature). Although continuous mode operation is favorable, batch-photobioreactors have been more studied and developed until now. Among these the anaerobic sequencing batch reactor has been proved to be the most practically efficient [9]. The use of flat panel photobioreactors has many advantages for large scale applications, like the good utilization of sunlight and the high photochemical efficiency. However, panel photobioreactors seem to have big power consumptions and this is one main drawback. Better design and research are needed to establish sustainable large-scale biohydrogen production on panel photobioreactors [24]. Considering theoretical efficiency, tubular photobioreactors seem to be more favorable, however in practice there are some major bottlenecks for their use. One main problem is the need for maintenance of low hydrogen partial pressure inside the reactor, something that can be achieved through clever design and continuous removal of the produced hydrogen from the photobioreactor system [24].

Finally, the high cost of the majority of photobioreactors is a factor that holds back the application of photohydrogen production in industrial scale. A solution might be the development of high-tech polymers that are hydrogen impermeable. This improvement can reduce the costs of these reactors and solve one major problem of these methods for practical application [33]. 


\subsection{Perspectives of hybrid photo-dark fermentative systems}

Maybe the most efficient system among all that have been discussed is a hybrid photo-dark fermentative system. Dark fermentation is another biological fermentative process that can produce biohydrogen [35]. During this process apart from hydrogen, VFAs (Volatile Fatty Acids like acetate and butyrate) are produced as by-products. These organic acids can be utilized further as carbon source for photo-fermentation [36]. By combining these two processes the system's efficiency can be widely increased. For example, the theoretical production of 4 moles of hydrogen per mole hexose in dark fermentation can be enchanted to 12 moles of hydrogen per mole hexose. Except for efficiency reasons, another advantage of this hybrid system is the conversion of the environmentally pollutant VFAs into an environmentally friendly fuel like hydrogen [24]. This hybrid system can specifically be used for biohydrogen production from wastes. Experiments have taken place utilizing cassava starch, rice straw, molasses, and many other wastes in a hybrid dark-photo fermentative biohydrogen producing system [21].

The dark-photo hybrid system can be further categorized into sequential and mixed dark-photo system [37]. The sequential dark-photo system offers many advantages for improved biohydrogen production over single stage production via photo or dark fermentation. In this sequential system, each dark and photo fermentation process needs to be performed in two different bioreactors, which is a significant cost factor of this system. During the first stage of the process (dark fermentation), hydrogen is being produced by thermophilic and mesophilic bacteria, along with carbon dioxide and some organic acids as by-products (butyrate, lactate, acetate etc.). These effluents usually need pretreatment before they get into the photo-fermentative system. After pretreatment (if needed), the organic acids produced in stage 1 are being transferred in a separate photobioreactor where are utilized as substrate for further biohydrogen production though photo-fermentation $[21,38]$. By implementing this approach, one of the major disadvantages of photo-fermentation which is the limitation of production period (production cannot take place at night because there is no sunlight) can be surpassed. The first stage of the system can take place at night, as dark-fermentation does not need sunlight to produce hydrogen, while the second stage which is photofermentation can take place in daylight.

Regarding the mixed photo-dark approach, one single bioreactor is being used which contains a co-culture of both dark and photosynthetic bacteria [37]. The dark bacteria utilize the substrate to produce $\mathrm{H}_{2}, \mathrm{CO}_{2}$ and VFAs, while the photo-fermentative bacteria (like PNS) convert VFAs into additional hydrogen and carbon dioxide. By implementing this approach, the need for $\mathrm{pH}$ adjustment is eliminated because the acidophilic VFAs are being consumed so the $\mathrm{pH}$ variations are less. Additionally, production time is reduced comparing to the sequential system [38].
The hybrid mixed dark-photo fermentation system was studied by Rashmi Chandra and S. Venkata Mohan (2014), [37]. This method aim was to enhance hydrogen production along with wastewater treatment.

The hybrid system seems to be one of the most effective in biohydrogen production, offering a wide range of wastes that can be utilized and multiple bacterial strains. Through the dark-photo hybrid system, the economical level of $8 \mathrm{~mol}$ $\mathrm{H}_{2}$ / mol glucose can be achieved.

In terms of financial viability, the hybrid system seems to be preferable because the cost is estimated between 2.5 and $2.8 \$ / \mathrm{kg}$, comparing to photo-fermentation and darkfermentation which cost is $3.7 \$ / \mathrm{kg}$ and $18.7 \$ / \mathrm{kg}$ respectively [1].

\section{Conclusions}

In this review paper, it was explored that both biophotolysis and photo fermentation can potentially be realistic routes for biohydrogen production in the future, while intense $R \& D$ efforts are needed. They both present advantages and bottlenecks for their commercial application.

In the transition to hydrogen circular economy $(\mathrm{CE})$, many types of waste have been investigated as biohydrogen production feedstocks. They provide many prospects for a sustainable biohydrogen production.

Different strains of cyanobacteria (biophotolysis), microalgae (biophotolysis) and PNS bacteria (photo fermentation) have been demonstrated as having the potential for biohydrogen production.

Genetic engineering and biotechnological approaches, chemical implementation and hybrid system consisted of both dark and photo fermentation may be potential solutions towards enhancing the biohydrogen production yields.

Hybrid systems consisted of both dark and photo fermentation seem to be more attractive in terms of financial viability, due to lower cost per $\mathrm{kg}$ of hydrogen compared to stand-alone photo-fermentation and darkfermentation.

\section{References}

1. S. Rezania et al., Review on fermentative biohydrogen production from water hyacinth, wheat straw and rice straw with focus on recent perspectives, Int. J. Hydrogen Energy 42, 20955-20969 (2017)

2. P.M. Budiman, T.Y. Wu, Role of chemicals addition in affecting biohydrogen production through photofermentation, Energy Convers. Manag. 165, 509-527 (2018)

3. A.F. Ferreira et al., Biological hydrogen production by Anabaena sp. yield, energy and $\mathrm{CO}_{2}$ analysis including fermentative biomass recovery, Int. J. Hydrogen Energy 37, 179-190 (2012)

4. R.H. Bezdek, The hydrogen economy and jobs of the future, Renew. Energy Environ. Sustain. 4, 1 (2019)

5. J. Rongé, T. Bosserez, L. Huguenin, M. Dumortier, S. Haussener, J.A. Martens, Solar hydrogen reaching maturity, Oil Gas Sci. Technol. Rev. 70, 863-876 (2015) 
6. P. Mishra et al., Outlook of fermentative hydrogen production techniques: an overview of dark, photo and integrated dark-photo fermentative approach to biomass, Energy Strategy Rev. 24, 27-37 (2019)

7. S.N.A. Rahman et al., Overview biohydrogen technologies and application in fuel cell technology, Renew. Sustain. Energy Rev. 66, 137-162 (2016)

8. S. Anto et al., Algae as green energy reserve: technological outlook on biofuel production, Chemosphere 242, 125079 (2020)

9. S. Mona et al., Green technology for sustainable biohydrogen production (waste to energy): a review, Sci. Total Environ. 728, 138481 (2020)

10. S. Srikanth et al., Acetate and butyrate as substrates for hydrogen production through photo-fermentation: process optimization and combined performance evaluation, Int. J. Hydrogen Energy 34, 7513-7522 (2009)

11. S. Ghosh et al., Hydrogen from food processing wastes via photofermentation using purple non-sulfur bacteria (PNSB) - a review, Energy Conv. Manag. 141, 299-314 (2017)

12. B.S.F. Boodhun et al., Research perspectives on constraints, prospects and opportunities in biohydrogen production, Int. J. Hydrogen Energy 42, 27471-27481 (2017)

13. T.Y. Wu et al., Recent advances in reuse of waste material as substrate to produce biohydrogen by purple non-sulfur (PNS) bacteria, Renew. Sustain. Energy Rev. 16, 3117-3122 (2012)

14. K. Bolatkhan et al., Hydrogen production from phototrophic microorganisms: reality and perspectives, Int. J. Hydrogen Energy 44, 5799-5811 (2019)

15. R. Kothari et al., Fermentative hydrogen production-An alternative clean energy source, Renew. Sustain. Energy Rev. 16, 2337-2346 (2012)

16. G.K. Dinesh, R. Chauhan, S. Chakma, Influence and strategies for enhanced biohydrogen production from food waste, Renew. Sustain. Energy Rev. 92, 807-822 (2018)

17. N.C. Dasgupta et al., Recent trends on the development of photobiological processes and photobioreactors for the improvement of hydrogen production, Int. J. Hydrogen Energy 35, 10218-10238 (2010)

18. D. Sengmee et al., Biophotolysis-based hydrogen and lipid production by oleaginous microalgae using crude glycerol as exogenous carbon source, Int. J. Hydrogen Energy 42, 1970-1976 (2017)

19. J.X.W. Hay et al., Biohydrogen production through photo fermentation or dark fermentation using waste as a substrate: overview, economics, and future prospects of hydrogen usage, Biofuels Bioprod. Biorefin. 7, 334-352 (2013)

20. E. Eroglu, A. Melis, Microalgal hydrogen production research, Int. J. Hydrogen Energy 41, 12772-12798 (2016)

21. M.Y. Azwar, M.A. Hussain, A.K. Abdul-Wahab, Development of biohydrogen production by photobiological, fermentation and electrochemical processes: a review, Renew. Sustain. Energy Rev. 31, 158-173 (2014)

22. M.F. Tiang et al., Recent advanced biotechnological strategies to enhance photo-fermentative biohydrogen production by purple non-sulphur bacteria: an overview, Int. J. Hydrogen Energy 45, 13211-13230 (2020)
23. X. Li et al., Enhancement of phototrophic hydrogen production by Rhodobacter sphaeroides ZX-5 using a novel strategy-shaking and extra-light supplementation approach, Int. J. Hydrogen Energy 34, 9677-9685 (2009)

24. K.Y. Show et al., Biohydrogen production: current perspectives and the way forward, Int. J. Hydrogen Energy 37, 15616-15631 (2012)

25. S.I. Allakhverdiev et al., Photosynthetic hydrogen production, J. Photochem. Photobiol. C 11, 101-113 (2010)

26. J. Mathews, G. Wang, Metabolic pathway engineering for enhanced biohydrogen production, Int. J. Hydrogen Energy 34, 7404-7416 (2009)

27. S.S. Oncel et al., Biohydrogen production using mutant strains of Chlamydomonas reinhardtii: the effects of light intensity and illumination patterns, Biochem. Eng. J. 92, 47-52 (2014)

28. B.D. Kossalbayev et al., Determination of the potential of cyanobacterial strains for hydrogen production, Int. J. Hydrogen Energy 45, 2627-2639 (2020)

29. R.A. Loss et al., Biohydrogen production by a mixed photoheterotrophic culture obtained from a Winogradsky column prepared from the sediment of a southern Brazilian lagoon, Renew. Energy 50, 648-654 (2013)

30. E. Boran et al., Biological hydrogen production by Rhodobacter capsulatus in solar tubular photo bioreactor, J. Clean. Prod. 18, S29-S35 (2010)

31. M.C. Akman et al., Investigation of the effects of initial substrate and biomass concentrations and light intensity on photofermentative hydrogen gas production by Response Surface Methodology, Int. J. Hydrogen Energy 40, 5042-5049 (2015)

32. G.R. Kumar, N. Chowdhary, Biotechnological and bioinformatics approaches for augmentation of biohydrogen production: a review, Renew. Sustain. Energy Rev. 56, 1194-1206 (2016)

33. P.C. Hallenbeck, M. Abo-hashesh, D. Ghosh, Strategies for improving biological hydrogen production, Bioresour. Technol. 110, 1-9 (2012)

34. T. Da Silva Veras et al., Hydrogen: trends, production and characterization of the main process worldwide, Int. J. Hydrogen Energy 42, 2018-2033 (2017)

35. K. Trchounian, R.G. Sawers, A. Trchounian, Improving biohydrogen productivity by microbial dark-and photofermentations: novel data and future approaches, Renew. Sustain. Energy Rev. 80, 1201-1216 (2017)

36. A. Singh et al., Biohydrogen production from lignocellulosic biomass: technology and sustainability, Energies 8, 13062-13080 (2015)

37. R. Chandra, S.V. Mohan, Enhanced bio-hydrogenesis by co-culturing photosynthetic bacteria with acidogenic process: augmented dark-photo fermentative hybrid system to regulate volatile fatty acid inhibition, Int. J. Hydrogen Energy 39, 7604-7615 (2014)

38. K.P. Rai, S.P. Singh, Integrated dark-and photo-fermentation: Recent advances and provisions for improvement, Int. J. Hydrogen Energy 41, 19957-19971 (2016) 